\title{
Community and Neighbourhood in Egyptian Context, Case Formal and Informal Settlements - Cairo
}

\author{
Sarah Eldefrawi
}

\begin{abstract}
-in modern society due to means of communication we expect that local social ties do not play a role in neighbourhoods. This research examines social ties in relation with neighbourhood in Egyptian context. The research is based on evidence, observations and interviews with residents to understand local communities' ties, solidarity and integration in two different residential settlements: Formal that was planned by government and Informal that was built by community. By analysing processes, relations and networks in the two settlements exploration indicates that informal settlements kept the status of saved community with tight solidary ties moreover community use technology like internet to save local networks more than liberate them. On the other hand formal settlements residents social network are more liberated than kept on the local level. In both settlements built environment is impacting directly and indirectly local ties but on another level the formation process of informal settlement is also reason of strong network.
\end{abstract}

Index Terms-Local communities, formal and informal settlements, community networks and ties, built environment.

\section{COMMUNity AND NeIGHBOURHOOD IN THEORY}

End of 19th century different arguments began consequent to the industrial revolution discussing the meaning of community and its relation with neighbourhood. Many raised questions about the impact of industrial revolution on city structure and on primary ties in homes, neighbourhood, workplace and kin. Have such ties attenuated or flourished in contemporary societies? In what sort of networks are they organized and have the contents of such ties remained holistic as alleged as before? Sociologists in 19th century introduce studies related to community and neighbourhood, such as Tönnies (1887) [1] who was concerned about the decline of social bonds and solidarity in local communities. Later other scholars argued that people are members of many liberated communities. Neighbourhood as a place for identification that continues to play a role is still being proposed by recent studies [2]-[4].

Lost, Saved or liberated Communities?

Wellman and Leighton (1979) introduced theories that contended for a relation between community and neighbourhood in three arguments "lost, saved and liberated" that was based on question whether "neighbourhood" and " community" are in relation or not. [5] They indicated that the lost argument like Tönnies in "Community and society" 1887, Durkheim in "The Division of labour in Society" 1893, asserts an absence of local

Manuscript received December 15, 2013; revised February 11, 2014.

Sarah Eldefrawi is with the Housing and Building National Research Center (HBRC), Egypt (e-mail: sarah.defrawy@gmail.com). solidary ties in contemporary society, in particular in urban neighbourhoods while scholars of saved argument like Whyte in "Street corner society" 1955, Jacobs in "The Death and Life of Great American Cities" 1961, Gans in "Urban villagers"1962 and Liebow in "Tally's corner" 1967, argue for a considerable social solidarity to be found in contemporary society, indeed in urban neighbourhoods. Community liberated argument led by Wellman since 1979 sets out a new line of argument that a variety of structural and technological developments have liberated communities from the confines of neighbourhoods to dispersed network ties from all embracing solidarity to more narrowly based ones. These arguments consequently was tackled by different approaches to the study of social networks, relationships and contacts situated in the context of debates on the interpretation of the changing nature of 'community'. Three approaches are considered; a traditional 'community as locality' approach that sees contacts as bound to a particular geographic location; 'social network analysis' that considers the 'networked' nature of an individuals' contacts; and the idea that individuals are connected through 'small worlds' that attempt to understand the linked nature of different networks [6], [7].

Delanty (2003) is categorizing in his overview of social science research on "community" four ways. The first concerns with the formation of social organizations into small groups such as neighbourhoods, small towns or other spatially bounded localities. A second applies the term to ideas of belonging and difference around issues such as identity. A third position considers community as a form of political mobilization inspired by radical democracy that prompts 'communities of action' to oppose social injustice. The last type is related with global society, transnational mobility, global communications and the internet [7], [8].

\section{COMmunity AND NeIGHBOURHOOD IN EGYPT}

The Egyptian traditions are basically based on close inter personal connections. Neighbours and meaning of neighbourhood is considerable in Egyptian context. A widely used proverb while looking for a house called "al gar abl al dar" (neighbours before the house). This indicates to the neighbourhood perception in Egyptian community as while choosing settling location, residents consider neighbours more than the quality of housing. The question on how much this proverb is presented in nowadays middle and low middle class urban neighbourhoods even those groups are effected with modern means of communication like mobiles and internet (Facebook and Twitter), which are methods could change solidarity ties and change the level of interaction in 
neighbourhood and whether neighbourhood built environment would impact the sense of community or not?

Here we are tackling the three criteria defined by Wellman, 1.residence in a common locality, 2.networks of interpersonal ties, 3.solidarity sentiments and activities, to understand social ties and networks in Egyptian neighbourhoods and to explore the status of community in relation with the two approaches: 'community as locality' or 'social network' [7].

To understand the status of community in Egyptian neighbourhoods, the paper also present the processes of creating settlements as it plays major role in social ties within those areas.

\section{A. Residence in Common Locality}

The research will focus on two types of neighbourhoods in Egyptian context "Formal and Informal"

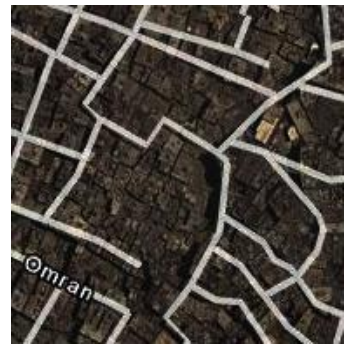

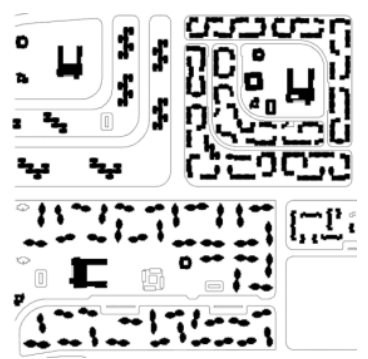

Fig. 1a. Left Manshiet Nasser (source: Google map), b. Right 6th of October (source: Shehayeb et al. 2003).

\section{1) Informal settlement}

The development of informal settlements follows special patterns, movement, and location of activities that are mainly structured on social ties. Two types of informal settlement existing in Egypt: Informal settlements that have been emerged on state desert area such as Manshiet Nasser and Ezbat Khayralla and informal that is growing on agriculture land (usually private land) such as Boulaq Al-Dakrour [9]-[10] Land tenure is not the distinguished criteria between the two settlements but we are here concerned with processes of occupation in both settlements that impact social networks and bonds strength and create community of locality.

\section{a) Desert informal settlements}

Informal settlements that are growing on desert state land are structured on three phases: Settlement, Familiarization, and Proliferation. (See Fig. 2) The settlement phase started in the 60s when individual young people emigrated from Upper Egypt to the capital [11]. In this phase, the physical structure of the area was still not shaped but there was a continuous subdivision of land with small dimensional plots adapted according to settlers needs. Later on, after the improvement of socio-economic life of the settlers, they began to bring their families and invite relatives to join them in the new location [12]. That's when the phase of familiarization began. The old settlers helped new ones in finding jobs and settling in the same settlement area. After settling down, those new settlers brought the rest of their families and so on. That's when the last phase; the proliferation began. Manshiet Nasser is one of these settlements, where people started to settle in 50s to work in the stone quarries on the foot of the Moqattam Mountain. Today, it is the home of 800,000 people. Most of the families living there are originally immigrants from three areas in Upper Egypt; Qena, Fayyum, and Sohag and they are in strong social relation [13].

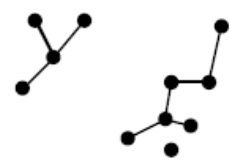

First Settler (empty land)

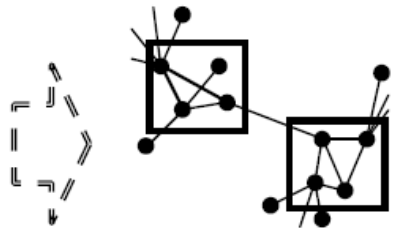

Familiarization and Proliferation
Fig. 2. Social ties growing on Informal desert lands.

\section{b) Agriculture informal settlement}

Other informal settlements are growing for reason of the extension of urban cordons to include inside them villages. The land in-between urban and village are growing consequently informally as in most cases those lands are agriculture lands that are not allowed to build on them. (See Fig. 3) The village of Mit-Oqbah is one of those models that were included in Great Cairo at the end of 90s. Mit-Oqbah now is an informally growing neighbourhood in Mohandessen area. Here the process of occupation is different than desert lands as two factors impact occupation, the division of agriculture land and lands owner which consequently impact social patterns and network. In this case networks are weaker than in desert settlements [14].

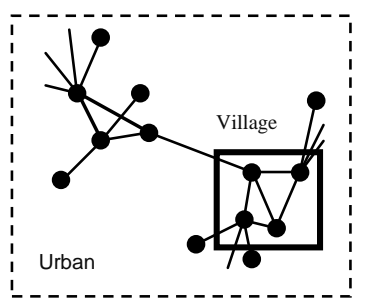

Fig. 3. Social ties in informal settlement growing on agriculture land.

\section{2) Formal settlement}

The new towns and new settlements are presenting Egyptian formal settlement such as $6^{\text {th }}$ of October, Sheikh Zayed and Alsherouk. The goal of establishing those settlements is conveying residents out of agriculture land to desert land. Different land tenures exist in those areas. [9] Some lands are privately sold, others are sold as built units for low income residents that are called "co or popular housing", others that spread out widely in last 10 years called gated communities. Gated communities are targeting upper middle class even recently many middle class are also included in those areas but co-housing is still the main formal settlement where they live. Co-Houses are built all-over Egypt with same characteristics "Several Separated blocks from 6 to 8 floors with very wide streets and in between large gardens with mono use (no mixed uses)" Processes for establishing those settlements are not including residents and are controlled by many rules such as density of built area, heights...etc. Here is clear that the absence of resident contribution in establishing settlements is impacting 
directly and indirectly the social bonds in those areas. (See Fig. 1b).

\section{B. Interpersonal Ties}

Interviews that were held in different local urban communities that are informally growing like (Manshiet Nasser, Dar Al Salam, Boulaq al-Dakrour, Mit Oqbah) in Great Cairo are validating that residents living in informal areas tend to be heavily involved members in their neighbourhoods. Four interviews: Gado in Boulaq Al-Dakrour, Shehayeb and Eid in Dar el Salam, Gerlach in Manshiet Nasser additionally the author in city of dead and Dowaika, indicate to tight boundaries, and multi-stranded ties networks in informal areas. Gado (2009) in her interviews with women from Boulaq al-Dakrour is stating that there are strong families' ties as well as strong sense of community in the neighbourhood. For instance in her interview with a Nubian middle aged woman declares: "I feel safe in my area and I never feel bored. The movement in street continues till late night and I can go out on the balcony and greet my neighbours. They offer help by doing some shopping for me and even used to baby sit for my kids when I had an errand to run." Insherah also mentioned: "I feel belonged to Boulaq al-Dakrour. I feel comfortable in the area." Amani who don't feel belonged to Boulaq al-Dakrour, she still emphasize on: "The only beauty in the place occurs in its "sense of neighbourhood" and I feel happy when she sees the strong bond among people and the way they share moment of happiness and distress." Faten, a young girl that plans after marry to live also in Boulaq al-Dakrour says "I feel at home in Boulaq al-Dakrour" [15].

Jihan from Manshiet Nasser is explaining with proudness her relationship between herself and the two women already sitting in her living room, Farhan is coming from upstairs. "I need to go to the market. Could you just take care of Adnan for a little while?" Other residents are focusing on how everybody in the area knows all people living there and how this condition impact safety within the area. Interview of Gerlach with Rahma, she mentions: "I still think people here know each other better than in other parts of town. People watch each other and they know who is who, and who the father of whom". For her, this is one of the reasons why the streets of Boulaq al-Dakrour are safer than elsewhere. Umm Amr in Manshiet Nasser observes: "If anybody does anything wrong, it will get back to his family," [16].

From the four interviews common keys are referring to this strong Interpersonal ties. Primary and secondary ties of residents were included within the same area of settlement. Keys are as following:

\section{1) People to count on}

The vast majority of interviewed residents felt able to be themselves with key trusted individuals in their neighbourhood and felt that they had people both to count on them from neighbours. The common support is amongst interviewers appeared in child care either as an ongoing arrangement or on when needed.

\section{2) Family links}

Family contact and family help was mentioned by most of interviewed residents. Also many declared relatives are living in same neighbourhood.

\section{3) Friends}

Majority of interviewed residents mentioned meeting with friends that are neighbours or live within same neighbourhood. They mentioned that not only they relayed on them in emergency but also to sit together and place daily chat that sometimes consist of more than two persons from same neighbourhood.

\section{4) Social trust}

A high level of social trust described by the interviewed residents by mentioning account of their relationships with neighbours, as did the frequency of favours exchanged with neighbours, which were wide ranging and covered both longstanding and ongoing arrangements. The most common value added by social trust and neighbourliness was feeling safe in the region.

\section{5) Regeneration initiatives}

Many of residents specially the one under 35 years old refereed to their involvements with regeneration initiatives and groups in their neighbourhood.

On another level while observing formal settlements local community ties and networks, it presents a totally different knit than informal one. Community ties in formal settlements like 6 October, Al Sheikh Zayed and Al Sherouk, are limited, in terms of amount, intensity and commitment of interaction. Primary and secondary ties are narrowly defined; there are fewer strands in the relationship. Generally ties tend to be weak, fragmented into two-person relationships rather than being parts of extensive networks within the neighbourhood. Shehyeb and Eid research (2007) present those factors in their survey on social interactions in $6^{\text {th }}$ of October. Results showed the lowest ratios in social bonds and networks such as visiting neighbours, relatives or friends even network outside the neighbourhood was limited in amount intensity and commitment in comparison with Dar el Salam which showed a much higher ratio in social interactions. However for shared activities such as buying and providing support to neighbours was not that limited.

\section{Evidence on Neighbourhoods and Community Ties}

\section{1) “Legan shaa'baya” 25th Jan revolution}

Wellman and Leighton (1979) described in their saved argument that tight Interpersonal ties facilitate the mobilization of assistance for dealing with emergency matters. This was obvious in informal settlement in the first 18 days of $25^{\text {th }}$ Jan revolution, when neighbourhoods all over the country challenged security gap by creating popular committee "Legan shaa'baya" to protect neighbourhoods. Committees that were created in informal neighbourhoods were strong and could sustain longer than the one in formal areas. Those groups created in informal settlements continued active until nowadays however their missions were developed from watching neighbourhood to being advocated for community development and reform. In informal settlements popular committees contributed to extract the provision of essential state services "gas lines, lighting and health clinics". [18]-[19] This sustaining condition that was kept in informal settlement than formal one was due to 
densely knit and tightly bounded networks, multiple strands of relationships between members of neighbourhood. Contradicting to the liberated argument of using technology to liberate relation outside neighbourhood [20], as by opposite technology in this statement was used to emphasize on the saved statement. Each committee created a Facebook group to enlarge the circle of network within the neighbourhood and share ideas and actions that at the end created influencing community practices. [18], [19] On the other hand narrowly dispersed network in formal settlements has created difficulties in mobilizing assistance and found difficulties to continue developing activities and contributing in neighbourhood watching after the 18 days. (See Fig. 4) Approving the status, an interview was held by author with number of teens living in formal and informal areas about the 18th days of revolution. For informal settlements teens didn't show special incident as for them contacting neighbours and stay with them in streets overnights was something not special but for formal settlements, particularly interviews was done with teens from $6^{\text {th }}$ of October, showed excitements to this experience as they could get know their neighbours in general and those ones they knew before only by names or Figure, they could recognize and create deep relation with them. They also kept some of these relations. Likewise they stated that they are welcoming this experience and would be glad if this statement stayed longer.
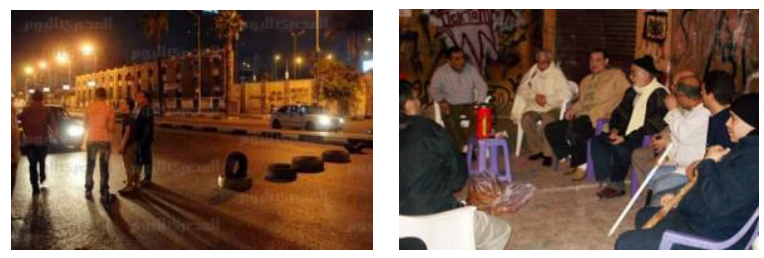

Fig. 4. Protection committee in $25^{\text {th }}$ of January 2011 illustrates weak and strong ties. (a). formal settlements (left) (b). Informal (right) settlements (source: al jazeera website).

\section{2) Basatin}

One of the models illustrating popular committee status is Basatin neighbourhood. Basatin is one of the informal settlements west Cairo and as in other parts of Cairo, Basatin's residents are from different labour categories, mainly middle and low middle class where many own small workshops in the area. According to the founders of Basatin's popular committee, the majority of the volunteers for the neighbourhood committee were second-generation residents whose families owned local businesses. They tended to be professionals themselves, lawyers, engineers, real estate brokers and doctors but their initial concern was clearly the safety of the family business and its customer base. Shortly after Mubarak stepped down, the popular committee established a Facebook group called the Enlightened Youth of Basatin: "The youth of Basatin can change what they do not like in this historic place". Under the banner "Toward a Better Basatin," the group organized a series of brainstorming sessions. These events concerned with cleaning streets, fixing water fountains and painting buildings. Proponents of these projects spoke of "showcasing Basatin as a 'civilized' area" and "reforming individual behavior in order to improve living conditions in the area."
The Basatin group gradually turned its attention to politics. It organized symposia to raise youth awareness of the constitutional amendments in the March 2011 referendum [18].

\section{3) Mit oqbah}

Mit Oqbah is also an accounted model presenting saved status and Gans "urban villagers" statement. Mit Oqbah was a village that entered Great Cairo cordon in 1990s. Mit Oqbah saved its strong bonds even after entering urban peripheries and being located between to upper middle class liberated neighbourhoods "Mohandessen and Dokki" [21]. On another level it used internet to emphasize on saving networks rather than liberate them. Here also we indicate to popular committee "Legan shaa'baya" in $25^{\text {th }}$ Jan revolution. Large amount of membership to this committee occurred since 2011 that are strong and influencing till nowadays. Those committees that were created from three years could enhance neighbourhood streets pavements and provide district with gas pipes. (See Fig. 5) Committee strong influence on neighbourhood was not only created by direct relation but also indirect contact between residents through internet as they created groups such as "Mit Oqbah Sound FB, and Mit Oqbah Committee FB" to strength local bonds and encourage solidary activities in their neighbourhood.

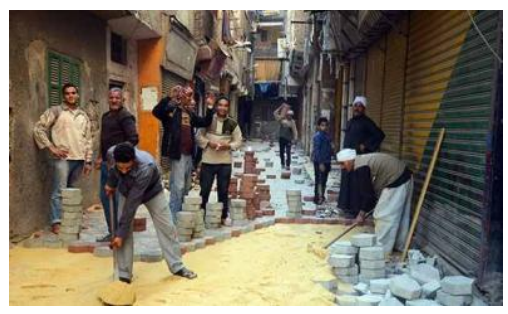

Fig. 5. Mit oqbah (source: tadamun website).

\section{Solidary Activities and Sentiment}

While Gans was describing West End neighbourhood, he was mentioning those crowded narrow streets alive with urban social life, same in most emerging informal settlements having narrow streets with very low traffic volume. Those cosy streets play special role to provide opportunity to create solidary activity and use them as shared space in the neighbourhood. It also provides feeling of being home (we feel home was mentioned in many interviews). The street as shared space is facilitating economical activities such as corner market and café that impact social bonds and strengthen solidarity within the neighbourhood. Those activities play role in keeping eyes all the day on streets by sellers and buyers. Opportunity to meet and control is an important factor that impacts social interaction in neighbourhoods [17].

The opportunity to control allows children to play in streets. Street as playground play vital role for community interaction, particularly children playing in same street of their homes. This provides social interaction between parents than it creates membership resulting emotional feelings between children and also between parents that creates strong network in the street of interaction. Also children existence in street strengthens not only opportunity of meeting but also indirectly raise the control in streets. By observation in 
different informal settlements many types of plays are occurring such as football, bicycle and running games more over children exploit urban pockets or in-between spaces for special games such as billiards and tennis tables. It is also important to highlight that children also play in the street in the formal neighbourhood but in a limited amount.

Many other solidary activities with heavily involvement from neighbourhood members are occurring in informal settlements such as Weddings, Ramadan and other ceremonies are held by participation of large number of neighbours. Ceremonies like weddings also take place within the neighbourhood streets or in between urban pockets on the contrary of formal settlements where most residents celebrate weddings in a rented halls commonly outside the neighbourhood and very few when neighbours are invited. Further practices are occurring in popular cafes. Cafes are used in informal settlements as shared space for meeting and entertaining furthermore in some cases showed support in parliament election for community members to compete with other candidates supported by regime.(See Fig. 6) Such support in many cases showed success for reason of mentioned tight and solidary network. Cafes in formal settlements are not structured in the urban context consequently residents most of the time entertain or sit on cafes outside the neighbourhood.
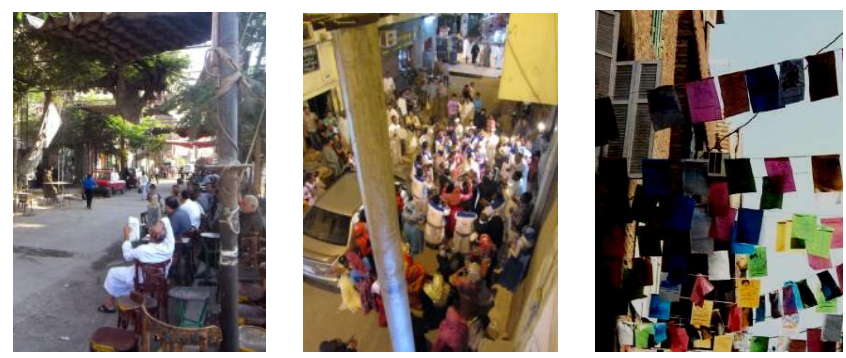

Fig. 6. Manshiet Nasser café, street wedding and Ramadan street decorations (source author and others).

\section{1) Doweika}

Short survey was held by author on the case of Doweika in Manshiet Nasser. The survey was done on the residents that were relocated from "Doweika" in Manshiet Nasser (Informal settlement) after part of the rock of Moktatam was collapsed in 2008 to a government planned area "Herafeyeen"(Formal settlement) that is also located in the Manshiet Nasser neighbourhood. This survey meant to understand informal communities' ties that are validating saved argument does those groups validate also Gans argument that lower-income class possess strong ties, to pool resources in order to protect themselves collectively against structural changes or processes and built environment are factors providing opportunities of creating saved statement?

The new fabric of Herafeyeen is totally different from the old Doweika. It consists of five separated buildings blocks on both sides of a street with approx. width $21 \mathrm{~m}$ (Formal Area). Old area was consisting of narrower streets that don't exceed $6 \mathrm{~m}$ wide and building blocks not more than 4 flours with a complex pattern was arranged by residents to fulfil their social and economic needs. Also streets had always a visual ending. (See Fig. 7-Fig. 9). An interview was held by author with a group of the relocated residents concern their relations, ties and activities in old and new settlements, we can summarize that many relocated residents kept relation with old area residents consequent of being relatives. Many mentioned that they don't let their children play in streets for security reason even they did in old area. Consequently the knit created through children in informal areas are missed in the new formal location. They also mentioned that they don't know neighbours in the last blocks on the contrary with the range of neighbours they knew in their streets in old district.

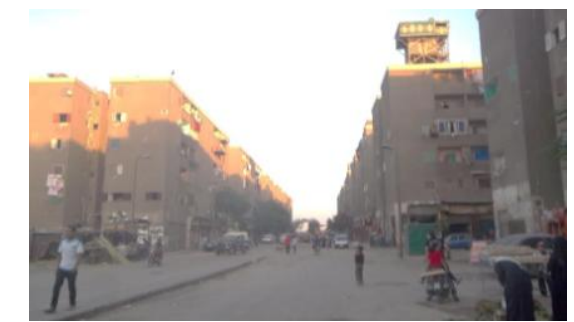

Fig. 7. Herafeyeen, Manshiet Nasser (source: author).

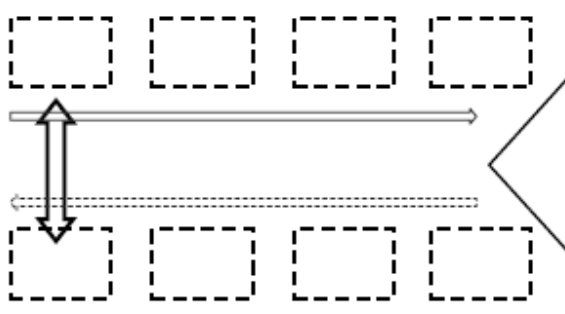

No Opportunity to meet

NoOpportunity to control

No Familiarization

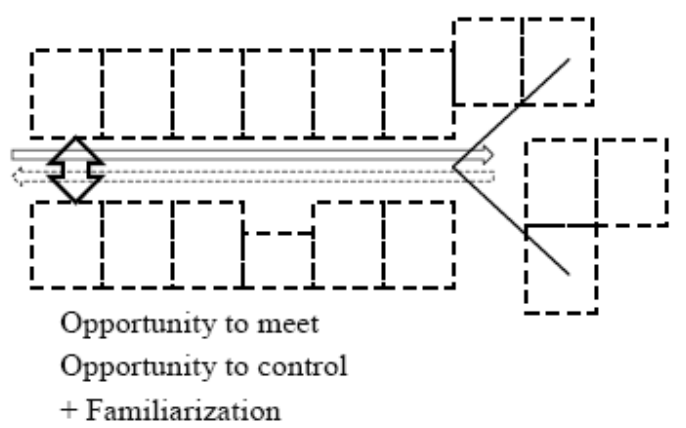

Fig. 8a. Formal (up), b. Informal (down) Urban opportunities (source: author).

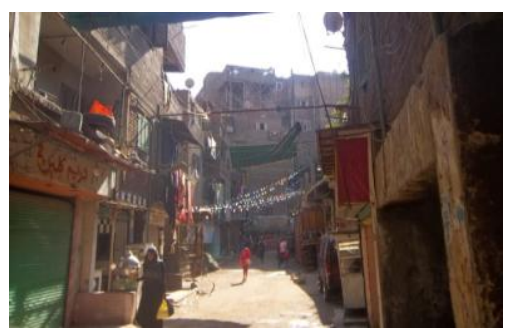

Fig. 9. Old doweika, Manshiet Nasser (source: author).

\section{CONCLUSION}

Along with the community and neighbourhood theories, Informal residents are communities from middle and low middle classes validating the saved argument. The fact that Gans argued for that lower-income class keep strong ties, to adapt to their environment and pond resources in order to 
protect themselves collectively against structural changes is also valid. This is apparent in proximity to relatives and that this proximity is highly valued. In that respect the community lost thesis, namely the claim that strong local networks do not play a role anymore, is not applicable to the informally growing settlements in Egypt. Those communities perform saved statement not only on the local level but more accentuated by using technology like internet (Facebook) to keep bonds strong.

Formal settlements showed more liberated community was social ties are not related with neighborhood. In this case formal settlements are validating Wellman argument that people are members of many liberated communities.

The Built environment feature and the processes of structuring communities play strong role for creating a saved or lost statement. In informal settlements, those factors are playing strong influence for establishing strong local ties, and tight networks that provide solidarity in activities, particularly involvement residents in process of structuring settlements, that subsequently impact the built environment feature to be built according to settlers economic and social needs.

In case built environment is providing opportunity to meet in feature and land use, social ties are stronger in term of amount, intensity and commitment of interaction. This was clear in the interview with teens of "Legan shaa'baya" in formal settlements as they showed welcoming of the idea of creating local strong ties, which approves how lack of meeting opportunity in formal urban fabric influenced their lifestyle more than they decided to choose liberated community statement.

\section{APPENDIX}

Interview with Herafeyeen residents included:

1) Number of neighbours known in the old and new settlement.

2) Number of Visits with neighbours in old and new settlement (day, week, month).

3) Number of recognized people who live in same block and last street block.

4) Number of neighbours identified by first name in both settlements.

5) Loan a neighbour some food or a tool or help a neighbour in an emergency.

6) If there is a problem on the block people who live here can get it solved. How was it before.

7) Safety in new and old settlements.

8) Personal investment in new and old settlements.

9) Attendance of neighbour events.

10) Children playing in street in old and new settlement.

\section{REFERENCES}

[1] F. Tönnies, Gemeinschaft und Gesellschaft' Leipzig, published, Germany, 1887
[2] T. Blokland, Urban Bonds: Social Relationships in an Inner City Neighbourhood, Wiley- Blackwell, 2003

[3] R. Atkinson, "Padding the bunker: strategies of middle-class disaffiliation and colonisation in the City," Urban Studies, pp. 819-832, 2006

[4] P. Watt, "Living in an Oasis: middle-class disaffiliation and selective belonging in an English suburb," Environment and Planning A, pp. 2874-2892, 2009

[5] B. Wellman and B. Leighton, "Networks, Neighbourhoods and Communities" Urban Affair Quarterly, vol. 14, pp. 363-390, March 1979

[6] J. Larsen, J. Urry, and K. Axhaussen, "Social networks and future mobilities," Report UK Department of Transport, University of Lancaster, IVT, ETH Zurich, 2005

[7] A. Clark, "Understanding Community: A review of networks, ties and contacts," ESRC National Centre for Research Methods NCRM Working Paper Series, University of Leeds, May 2007

[8] G. Delanty, Community, London Routledge, 2003

[9] C. Arandel and M. E. Batran, "The informal housing development process in Egypt," CNRS, France, no. 82, 1997

[10] Informal settlements development fund. (2008). [Online]. Available: http:// www.isdf.gov.eg

[11] D. Sims and M. Séjourné, "Residential informality in greater Cairo: Typologies, representative areas, quantification, valuation and causal factors," 2000

[12] M. Séjourné, "The history of informal settlements," GTZ Egypt, 20areas: Manshiet Nasser, City of Dead, Boulaq al-Dakrour, pp. 16-19, 2009

[13] J. Gerlach, "Three Cairo's informal areas between urban challenges and hidden potentials," GTZ Egypt, pp. 49-51, 2009

[14] A. Sirry, "Planning and project management phase-out relocation case study Mit Oqbah," Cooperation Egyptian Hollandaise THRUD, 2000.

[15] M. Gado, "Voices of women in Boulaq Al-Dakrour, Cairo's Informa Areas between Urban Challenges and Hidden Potentials," Egypt Independent ,pp. 60-64, 2009

[16] J. Gerlach, "Life is not always bad: cairo's informal areas between urban challenges and hidden potentials," GTZ Egypt, pp. 66-68, 2009

[17] D. Shehayeb and Y. Eid, "Neighbourhood Design and Community Building: A Model of Social Interaction," HBNRC, Cairo, Egypt, pp. 129-144, 2007

[18] A. E. Meehy, Egypt's Popular Committees From Moments of Madness to NGO Dilemmas, Published in MER265, Middle East Report, no. 26 2012

[19] M. E. Husseiny, "Enclaving the City: The housing question, the role of agency \& the architectural profession in 'Building [Communities]/Building [the Nation-State]' from Late-Colonial Egypt in 1940s till People's Revolution in 2011," University of California, Berkeley, USA, 2014

[20] B. Wellman, "Physical place and cyberplace: the rise of personalised networking," International Journal of Urban and Regional Research, vol. 25, pp. 227- 252, 2001

[21] D. Singerman and K. Ibrahim. (2013). Mit Oqbah Street Pavement. [Online]. Available: http://www.tadamun.info/?post_type=initiative \&p=2422\&amp;lang=a r\&lang=ar\#.UrDtwXFLwK0.twitter

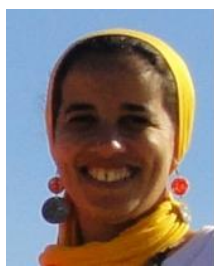

Sarah Hamed Eldefrawi was born in Alexandria, Egypt, in 1980. She received her Ph.D. student form the Cairo University at the Faculty of Engineering, Department of Architecture-Urban Planning, She received her M.Sc from Architecture DIA-Bauhaus, in Germany 2008 , He has been a worked for 10 years as an architect in national and international projects since 2011 affiliated at Housing and Building National Research Centre, Egypt, she is currently a research assistant. Ms. Eldefrawi is a specialist in community led projects, participated in several project on participatory planning and development in informal settlements. Eng. Eldefrawi was recently award in 2012 for competition of redevelopment of Manshyah Square Alexandria, Egypt. 